\title{
OS NAZISTAS ERAM DE ESQUERDA?
}

Prof. Dr. Antônio Ruzza ${ }^{66}$

\section{RESUMO}

97 O presente artigo tem o objetivo de argumentar contra a afirmação feita por alguns representantes ideológicos do governo brasileiro de que o nazismo foi um fenômeno de esquerda, porque no seu partido aparecia o nome "socialista" e ele fazia largo uso da violência. Como entendem a totalidade de historiadores sérios, o nazismo deve ser enquadrado na extrema direita, por uma série de motivos: o significado oposto dado ao nome "socialismo"; a intenção declarada de acabar com o marxismo; a chegada ao poder com o apoio das elites conservadoras e liberais, além das autoridades eclesiásticas; a propaganda anticapitalista nunca executada; a luta contra o Modernismo; a rejeição dos valores do Iluminismo e da Revolução Francesa, em particular a igualdade; uma política centrada no racismo e na superioridade alemã; o nacionalismo de dominação; a capacidade demagógica de apropriar-se das insatisfações e ressentimentos populares (populismo). Entendemos que todos esses elementos não fazem parte da ideologia esquerdista.

Palavras chave: nazismo; socialismo; esquerda; igualdade; raça.

\begin{abstract}
This article aims to argue against the assertion made by some ideological representatives of the Brazilian government that the Nazism was a phenomenon of the left-wing, just because the official name of the party mentioned the word "socialist" (National-socialist of workers) and also because the party used extensive violence to be in charge. As all serious historians understand, Nazism must be framed in the extreme right-wing, for many reasons: the name "socialism" took a different and opposite meaning into the Nazism party; the stated intention of ending Marxism; the party rised up to the power with the support of the conservative and liberal elites, in addition to the ecclesiastical authorities; anti-capitalist propaganda never carried out; the struggle against Modernism; the rejection of the Enlightenment and the French Revolution values, in particular equality; a policy centered on German racism and superiority; the nationalism of domination; the demagogic ability to appropriate dissatisfactions and resentments popular (populism). We understand that all these elements are not part of the leftist ideology.
\end{abstract}

Keywords: Nazism; socialism; left-wing; equality; race.

\section{INTRODUÇÃO}

\footnotetext{
${ }^{66}$ Graduado em Engenharia pelo Politécnico de Torino (Itália) e em Filosofia pela USJT. Pós-graduado em "Docência para o ensino superior" pela UNIFAI. Mestre em Filosofia (Epistemologia da Política e do Direito) pela USJT. Doutor em Filosofia pela PUC. Docente de Filosofia no UNIFAI, no qual organizou vários grupos de estudo. Publicou Rousseau e a moralidade republicana no Contrato Social (Annablume, 2010); Em nome das luzes: um desafio à religião (Annablume, 2012); A crítica de MacIntyre à Modernidade: Liberalismo, Individualismo e teorias da Justiça (CRV, 2018). Publicou o artigo $A$ solução para o problema do absurdo em Albert Camus no livro Deus entre a Filosofia e a Teologia Contemporânea, de 2014, editado pela Appris.
} 
Recentemente, a ala ideológica de extrema direita do governo Bolsonaro tentou afastar-se de uma compatibilidade com o nazismo ${ }^{67}$, copiando de alguns historiadores conservadores ou revisionistas a tese que esse movimento era de esquerda, por dois motivos principais.

O primeiro motivo consiste em destacar que os nazistas possuíam um discurso antiburguês e anticapitalista, com o uso do termo "socialismo" e da cor vermelha na bandeira. O segundo motivo se refere ao uso do terror e da violência, e à instalação de um regime totalitário com controle estatal em todas as atividades sociais e econômicas.

O objetivo deste artigo é argumentar contra os dois pontos.

\section{O PRIMEIRO MOTIVO}

Quanto ao primeiro ponto, mostraremos tratar-se de posições ideológicas e práticas bem diferentes nos valores, nos princípios, nos objetivos. Utilizaremos sete argumentos de caráter histórico e filosófico.

Pelo primeiro, observamos que a palavra "socialismo", em geral, significa ocupar-se e tentar resolver a questão social, surgida no século XIX por causa da oposição entre burguesia e proletariado após o avanço da Revolução Industrial. A solução pode ser oferecida pela esquerda, pelo centro, pela direita. Pela esquerda marxista, a solução consiste na eliminação das classes e da propriedade privada, ficando inicialmente tudo sob controle do Estado, que depois deveria desaparecer. No Manifesto do Partido Comunista, para defender o socialismo científico, Marx denunciou várias formas de socialismo, como a reacionária (que quer voltar a modelos econômicos feudais) e a pequeno-burguesa (indecisa a que classe deveria aliar-se). No final do século XIX, surgiu um socialismo de inspiração religiosa, baseado em virtudes cristãs, como a solidariedade: ele denunciava o capitalismo desumano e o egoísmo da burguesia. Tais posições aparecem também em discursos dos últimos papas, que fogem logicamente a qualquer enquadramento esquerdista.

Os nazistas entendiam que o socialismo era uma antiga instituição ariana e germânica, quando os antepassados cultivavam a terra e a ideia do bem comum. Não rejeitavam a propriedade privada, nem os valores patrióticos em oposição ao internacionalismo marxista. Defendiam uma política interclassista (isto é, negadora da existência das classes ou de conflito entre elas) que unia proletários e burgueses em um objetivo comum contra um inimigo comum, definido criminoso. Assim, as diferenças de classe desapareceriam (com cada indivíduo exercendo a sua função) e o trabalho seria executado pelos povos escravizados do Leste Europeu. O principal inimigo (interno) eram os judeus, considerados inventores tanto do capitalismo (por causa do pretenso gosto pelo dinheiro) quanto do comunismo (pelo desejo de

\footnotetext{
${ }^{67}$ A sigla oficial do partido era NDSAP (Partido nacional-socialista dos trabalhadores alemães). Podemos classificar o nazismo como parte da "família" do fascismo; no seu caso, levado ao extremo.
} 
dividir e destruir a nação por meio da revolução). Dezessete séculos de antissemitismo religioso facilitaram o objetivo nazista. ${ }^{68}$ Outro inimigo comum (externo) era a França, por causas das condições humilhantes impostas no Tratado de Versailles (no final da Primeira Guerra Mundial) e por usar tropas coloniais africanas no controle da Renânia, fato considerado ofensivo pela população branca alemã.

Tanto no Mein Kampf quanto em discursos públicos, Hitler sempre declarou a vontade de destruir marxismo e bolchevismo (comunismo russo), porque pregavam a luta de classes: ele os considerava produtos judaicos e queria arrancar das teorias deles a palavra "socialismo", porque Proudhon e Marx a teriam usurpado. Ela era uma palavra atrativa na época, e Hitler a usou com sucesso para confundir as massas populares, decepcionadas com os fracassos da revolução em Berlin e Munique (1919), e que caíram na armadilha do discurso populista contra as "elites", por causa do desemprego e da inflação. Argumentou que o socialismo dos comunistas oferecia um futuro utópico e um presente caótico, enquanto o dele prometia estabelecer a ordem, anular a humilhação da derrota militar e das duras reparações impostas pela França, recuperar o respeito internacional, eliminar o inimigo interno que provocou a derrota com a "punhalada nas costas". Na prática, o dele não era nenhum socialismo para enfrentar a questão social, mas um nacionalismo puro, que seria a cura para a decadência alemã, porque alimentava o revanchismo e o orgulho da "superioridade espiritual e racial" do povo alemão unido em todos os seus estratos, em oposição a todos os outros povos, para conquistar o seu "espaço vital" ao qual supostamente teria direito. Este objetivo militarista lhe angariou o apoio das cúpulas do Exército, que representavam a aristocracia do país. ${ }^{69}$ Esta facção, ao contrário, foi aquela que liderou a contrarrevolução na URSS, em cinco anos de guerra civil.

É verdade que no partido existia uma facção (as SA de Röhm) que completava aquela visão de socialismo pregando a socialização da produção e a expropriação dos ricos. Hitler mandou matar toda a liderança e vários militantes em única ação, porque o radicalismo verbal assustava os capitalistas e a homossexualidade abertamente praticada chocava os religiosos. Isso confirma de que parte ele estava.

Heidegger, fiel ao nazismo mesmo após a derrocada final, dizia que o "socialismo" é a "comunidade do povo alemão", que perde a sua identidade, perde a sua natureza "espiritual" que busca objetivos elevados, quando se transforma em "sociedade", porque esta é marcada pela diversidade de culturas, valores, objetivos:

\footnotetext{
${ }^{68} \mathrm{O}$ caráter dual do judaísmo (ser capitalista e comunista ao mesmo tempo), não foi uma invenção nazista. A teoria foi introduzida no final do século XIX por pensadores católicos conservadores, sobretudo franceses saudosistas do Ancien Régime e hostis à industrialização, que corrompia os costumes. Por exemplo, Edouard Drumont reúne estereótipos religiosos (matadores de Cristo, inspiradores de leis anticristãs como o ensino laico e o confisco de bens) e políticos (financistas, revolucionários, traidores da pátria, parasitas que atacam a sociedade por dentro). Para ele, Capitalismo e Comunismo eram as duas faces do judaísmo decidido a convulsionar o mundo e destruir o Cristianismo. Esta tese era defendida pelas revistas La Croix dos agostinianos e Civiltá Cattolica dos jesuítas, que misturavam antissemitismo religioso, racial e político. Assim, quando questionado por alguns bispos sobre as perseguições aos judeus, Hitler podia argumentar que estava executando os desejos e os planos das Igrejas (católica e luterana).

${ }^{69}$ Somente depois da conspiração de oficiais aristocratas liderados por Von Stauffenberg, que tentaram matar Hitler num atentado em 1944, é que houve a ruptura. Na sequência, o Fübrer retomou a propaganda contra a "aristocracia reacionária".
} 
Heidegger distinguia entre "seres autênticos" e "inautênticos", entre povos que assumem histórica e ontologicamente a "verdade do Ser", e os que intuitivamente são incapazes disso ... uma massa que não é um povo (Farias, 2017, p. 206).

Obviamente, o povo que realizou aquela espiritualidade em mais alto grau seria o alemão. Ainda hoje, Heidegger é o maior referencial teórico de revistas e grupos neonazistas e neofascistas, como o NPD alemão e a Nouvelle Droite francesa, porque:

Diante do indivíduo destemporalizado, desenraizado, do pensamento liberal-comunista, liberado dos laços orgânicos e concebido como um fenômeno interno, separado de um "fora" desconhecido, o Homem Heideggeriano atinge sua autenticidade por meio de uma apropriação dos laços multitemporais que compartilha com a sua comunidade [...] toda grande revolução pensa seu projeto como um retorno às origens (Farias, 2017, p. 138)..$^{70}$

Enfim, conforme nos mostrou Wittgenstein nas Investigações Filosóficas, o termo "socialista" é só um "nome" (como "liberdade" e muitos outros no discurso político), que tem um "significado" diferente conforme é "usado" em um jogo de linguagem diferente, definido pela cultura e pelas intenções da comunidade em questão.

Como segundo argumento, observamos que, para alcançar o poder, o líder nazista organizou movimentos paramilitares com extremistas e ressentidos de todo tipo contra a República de Weimar, ${ }^{71}$ incluindo veteranos de guerra, desempregados, monarquistas e sobreviventes dos "antigos regimes", intelectuais antimodernos, estudantes nacionalistas, antissemitas. Muitos deles eram considerados "marginais" ${ }^{72}$ indivíduos sem fortes raízes sociais que se voltavam para líderes carismáticos e salvadores da pátria, somente ligados entre si por um espírito de forte companheirismo, porque buscavam no grupo algo que os salvasse da falta de perspectivas:

O conceito de marginalidade tem influenciado muitas análises do nazismo. Naturalmente, o próprio Hitler adapta-se com perfeição ao estereótipo: pintor fracassado, migrante internacional, cabo dispensado, vegetariano numa época de carnívoros, homem sem uma verdadeira vida de família, provavelmente inativo sexualmente (Mann, 2008, p. 232).

Em contraposição, a esquerda sempre se apoiou em uma classe bem definida e organizada, dirigida por operários e intelectuais, recusando elementos marginais oriundos de qualquer grupo social

\footnotetext{
${ }^{70}$ Farias está relatando o pensamento do neofascista Michael Torigian, autor de Os Fundamentos filosóficos da Nova Direita Francesa. ${ }^{71}$ Com esse nome é conhecida a República que surgiu após a derrota na Primeira Guerra Mundial e a queda do Império Alemão. Era governada por uma aliança entre social-democratas e liberais. Ficou logo impopular, pela alta inflação e o desemprego, além do fato de ter aceitado as duras reparações de guerra, impostas pela França vencedora.

${ }^{72}$ Conforme bem explicado por Hannah Arendt em Origens do Totalitarismo, o fenômeno totalitário surge quando o indivíduo se sente isolado, sem raízes, faz parte de uma ralé ou de uma massa amorfa; portanto, aceita a propaganda de alguém que lhe oferece demagogicamente um objetivo comum, um inimigo comum e uma identidade. Hitler foi extremamente habilidoso nessa tarefa, graças à sua capacidade de orador e à personalidade magnética.
} 
e alimentados pela frustração e o ressentimento. O elemento psicológico foi infelizmente desprezado por Marx, que condenava como improdutivo o entusiasmo e o espontané́smo dos revolucionários, enfatizando o planejamento puramente e friamente racional. A este respeito, Wilhelm Reich:

[...] viu, na derrota dos comunistas e na ascensão de Hitler, a prova de que o marxismo era insuficiente, por si só, a explicar a realidade social e o fascismo, pois subestimaria a influência de fatores irracionais, subconscientes, nas atitudes dos homens. Reich buscava em Freud os elementos que considerava necessários para completar Marx. [...] Propunha que, na ascensão do nazismo, não devia ser esquecido o fato de que ele teria atingido o poder não só devido a seus programas ou ideias, mas sim graças aos seus apelos aos desejos obscuros da mente humana [...] fundamental na formação dos indivíduos dóceis, recalcados e sem espírito crítico que serão recrutados pelo fascismo [...] boa parte do sucesso do fascismo deveu-se a sua capacidade de apropriar-se dos medos e tensões humanas (Bertonha, 2008, p. 320-322).

Esses elementos psicológicos e irracionais, combinados a um contexto histórico social de crise e transformações profundas, fizeram do nazismo um movimento político atrativo, que nada tem em comum com o marxismo ou as esquerdas em geral, as quais podem avançar em um país razoavelmente estável, industrializado e com a economia em marcha, para poder fazer uma análise racional sobre as condições materiais e as reais possibilidades de revolução ou reformas ou avanços sociais.

Passemos a um terceiro argumento. A propaganda anticapitalista e "contra o sistema", presente de forma confusa na fundação do partido nazista, por volta de 1920, logo desapareceu, mostrando o grande oportunismo de Hitler:

O grande recuo se deu em relação ao "socialismo". Em 1928, o partido renunciou ao compromisso com uma reforma agrária radical. Seu anticapitalismo também começou a vacilar, passando a ser mais contestado no interior do movimento. Sob influência de Feder, Hitler estabelecera uma distinção entre capital "produtivo" e "improdutivo", sendo o primeiro autenticamente "alemão" e o segundo, internacional ou judaico. A partir de 1930, ele buscava a aprovação de empresários que não entendiam essa distinção. O "socialismo" nazista passou a receber menos ênfase em favor de uma reivindicação mais vaga e constantemente reiterada de uma "justiça social". Aí estava a grande ambiguidade nazista (Mann, 2008, p. 197).

Assim, quando Hitler chegou ao poder em 1933, o discurso anticapitalista ficou só no papel. Os feudos eleitorais do nazismo foram a pequena burguesia (que não queria correr o risco de cair no proletariado) e o lumpen-proletariat (tão desprezado por Marx, por ser ideologicamente reacionário e servil), além do mundo rural mais ligado às tradições e à religiosidade. Ele foi apoiado e financiado pelos grandes capitalistas e latifundiários, que viram nele um recurso decisivo para barrar a ameaça de revolução comunista, depois que ela triunfou na URSS. Os burgueses se adaptaram, sobrevivendo como classe proprietária, mas não mais dirigente. Os capitalistas (também hostis às reformas sociais de Weimar) 
perderam o poder político, mas mantiveram e aumentaram o econômico: ${ }^{73}$ não foram molestados nem confiscados, e prosperaram graças também à proibição de greves e sindicatos ${ }^{74}$. Mesmo sendo parte do "capital internacional”, as grandes empresas dos EUA (Ford, GM, IBM, etc.), com as filiais, fizeram grandes negócios na Alemanha. ${ }^{75}$ Evidentemente, nada disso aconteceu na URSS, isolada, sabotada e hostilizada.

Em suma, os nazistas se aproveitaram da democracia liberal (que se iludiu de poder controlá-los e liquidá-los no momento oportuno; mas depois foi liquidada), graças à liberdade de reunião e de manifestação, à proteção de autoridades policiais e ao financiamento de grupos dominantes. ${ }^{76} \mathrm{O}$ NDSAP foi o partido mais votado nas eleições de 1933, porém, sem maioria absoluta. Hitler foi escolhido chanceler (chefe do governo) pelo presidente da república, um conservador, que poderia ter optado por outra solução. Os esquerdistas não encontraram estas facilidades; pelo contrário, era mais provável que fossem reprimidos e perseguidos. Poderiam chegar ao poder somente por meio de uma revolução organizada e executada na rua, e não nos bastidores e conchavos da política tradicional. Esse fato demonstra que burgueses e capitalistas sempre tiveram bem clara a diferença entre os dois movimentos; e fizeram a sua escolha.

Um quarto argumento nos mostra que também a direita tradicionalista e conservadora (assustada com a queda dos impérios russo, alemão, austríaco e turco, após o término da Primeira Guerra Mundial), bem como as autoridades eclesiásticas, apoiaram Hitler, considerado ser um "mal menor" do que o comunismo, e por causa da sua luta contra os valores do chamado Modernismo (no qual eram incluídos o Liberalismo, o Marxismo, o Laicismo, a Democracia, o Materialismo e o Individualismo, considerados produtos do Iluminismo), ${ }^{77}$ em nome de uma totalidade orgânica, na qual o bem-estar do indivíduo está subordinado ao da nação-raça. Muitos elementos do Modernismo e do Iluminismo podem ser encontrados na ideologia esquerdista. O papa Pio XI assinou uma concordata (pacto especial, no mesmo modelo já experimentado com Mussolini) com o Führer logo após a sua ascensão ao poder, e ordenou

\footnotetext{
${ }^{73}$ Hitler via (corretamente) uma contradição entre o liberalismo político (que é democrático e tolerante) e o liberalismo econômico (que é autoritário e hierárquico). Por isso, quis eliminar somente o primeiro - apresentado como decadente, destrutivo e internacionalista. Aceitou a economia de mercado, porém, com controle político governamental. Tal visão não é absolutamente de esquerda.

${ }^{74}$ Segundo Hitler, os sindicatos eram uma invenção dos judeus, com a meta de sabotar e destruir a economia do Estado nacional (indústrias, comércio, etc.) e agravar os conflitos de classes, conforme o pretenso plano judaico de dominar o mundo. ${ }^{75}$ Ver a obra de Edwin Black, Conexão nazista, da Idea Editora (2018).

${ }^{76}$ Hitler seguiu o mesmo caminho de Mussolini, que fundou o Fascismo com o objetivo de destruir o Socialismo (dentro do qual iniciou a sua atividade política) e pôr ordem numa Itália que estava à beira da Revolução. Para chegar ao poder em 1922, ele teve apoio, proteção e financiamento da monarquia, do exército, da burguesia e dos latifundiários, apesar do costumeiro discurso demagógico "contra o sistema". Todas aquelas elites se iludiram, pensando de descartá-lo, depois de tê-lo utilizado para acabar com a esquerda, que foi realmente liquidada por meio da violência fascista que as elites não podiam ou não sabiam usar no regime democrático. Hitler admirava o líder italiano e aceitou várias ideias do Fascismo; porém, as levou a consequências mais radicais. Segundo Arendt, Mussolini (diferente de Hitler) não realizou um Estado totalitário, porque não conseguiu controlar todas as instituições: quando iniciou o declínio da sua popularidade, foi facilmente derrubado pelo antigo protetor (o rei) e pelos resistentes italianos (fato que não aconteceu com o líder nazista por parte dos alemães); e depois fuzilado.

${ }_{77}^{7}$ A campanha contra o Modernismo foi iniciada por Pio IX após os movimentos revolucionários de 1848 em Roma (quando foi obrigado a fugir, sendo reinstalado no poder por exércitos estrangeiros), na França e outros países europeus.
} 
que o partido católico se dissolvesse no partido nazista. $O$ objetivo não declarado (porém, não disfarçado), era uma firme união contra o comunismo, objetivo perseguido com mais ênfase pelo sucessor Pio XII. ${ }^{78}$ Será que a Igreja fez tais alianças porque considerava ser o nazismo de esquerda?

Em todo caso, as elites intencionadas em derrotar a esquerda, não entenderam aonde esse "mal menor" as levaria, porque os nazistas:

[...] não pensavam, realmente, em apenas resolver questões de classes e poder, mas em reverter a moral europeia, arrasar a herança do moralismo cristão e do humanismo iluminista, e criar um novo mundo baseado na biologia, na raça, na dominação e no ódio (Bertonha, 2008, p. 332).

Um outro ponto de distanciamento com relação à esquerda, o quinto, é a herança do Romantismo alemão anti-iluminista. Existiu no nazismo uma saudade da vida no campo (onde se encontrariam as autênticas tradições comunitárias, a pureza étnica do volk alemão, o espírito de autossuficiência, a maior natalidade), de um passado mítico glorioso (parcialmente inventado ou do qual foram expurgados os eventos negativos) e da família patriarcal (com a sua rígida hierarquia, que devia refletir-se na sociedade). ${ }^{79}$ Os nazistas mais jovens e intelectualizados:

[...] debatiam as ideias mais recentes, tentando combiná-las com o romantismo, o idealismo, a "espiritualidade" e o racismo da cultura alemã. Muitos acreditavam que a era liberal e burguesa entrara em colapso na guerra e no pós-guerra. A alternativa socialista parecia velha, materialista e por demais proletária para ser palatável aos intelectuais (Mann, 2008, p. 228).

O entusiasmo pela vida no campo, pelo passado mítico e pela família patriarcal teria sido destruído na cidade cosmopolita (em particular, Berlin e Viena, centros de grande fervor intelectual e artístico). A cidade era considerada uma fonte de irreligiosidade, de decadência moral, de arte degenerada, de baixa natalidade, de diversidade étnica, de corrupção de valores tradicionais por parte das minorias, de individualismo, de parasitismo, de assistencialismo, de influência judaica. A cidade representava o triunfo da vida material sobre a "espiritual". No polo oposto, os esquerdistas deram mais ênfase à cidade, onde a vida cultural era progressista e seriam mais fortes as contradições que levariam a uma revolução. Desconfiavam dos camponeses, que historicamente abasteciam as forças monarquistas e reacionárias durante as revoluções. Em suma, a concepção de "povo" era bem diferente: para os nazistas, em clara

\footnotetext{
78 A concordata não impediu o surgimento de vários atritos entre as duas partes, porque o líder nazista exigia a submissão completa das igrejas. Foi mais vantajosa para Hitler, que se apresentou como "homem da Providência" e defensor oficial do Cristianismo contra o comunismo ateu. Religiosos (católicos ou luteranos) contrários ao acordo foram silenciados. Esse "colaboracionismo" foi mais forte com Pio XII do que com Pio XI, que chegou a condenar algumas medidas racistas, na encíclica Mit brennender Sorge (Com ardente preocupação, escrita em alemão, em 1937). Consulte as obras: O papa de Hitler, de John Cornwell (editora Imago), O V aticano e Hitler, de Peter Godman (editora Martins Fontes), A Igreja Católica e os Judeus, de James Carroll, um ex-padre (editora Manole).

${ }^{79} \mathrm{O}$ papel da mulher é de ser mãe e esposa; o papel do homem é ser provedor e protetor. O feminismo seria mais uma conspiração dos judeus para enfraquecer a sociedade e a família cristã, porque entre eles prevalece o matriarcado. No polo oposto, a esquerda defendia para a mulher um papel mais ativo na sociedade.
}

Revista Lumen, v. 4, $\mathrm{n}^{\circ}$ 7, Jan./Jun. - 2019 - ISSN: 2447-8717 
oposição aos marxistas, o povo era elogiado não por ser revolucionário, mas por ser o guardião das tradições; a burguesia era desprezada não por explorar os trabalhadores, mas por ter aceitado (ou até criado) os valores do Modernismo, levando uma vida "materialista" e individualista, longe da "espiritualidade" e da comunidade.

Passamos a um sexto argumento, aquele que, talvez, seja o ponto que mais distancia as duas linhas. Os nazistas (como os reacionários e saudosistas do Ancien Régime) odiavam o pensamento iluminista e os lemas da Revolução Francesa, em particular o da igualdade, apresentado nos aspectos jurídico, político e moral (na época da Revolução, não era ainda considerada importante a igualdade econômica e social). Apesar de ser uma revolução essencialmente burguesa, ela foi apreciada por Marx, por ter liquidado o sistema feudal e por preparar indiretamente a revolução proletária. Os nazistas defenderam a desigualdade natural entre indivíduos, géneros, raças, nações e povos, classificados numa escala entre superiores e inferiores, e apelaram a teorias pseudocientíficas (darwinismo social, ${ }^{80}$ frenologia, ${ }^{81}$ eugenia $^{82}$ ) ou a preconceitos e estereótipos enraizados. A ala "intelectual” deu uma interpretação própria e equivocada do "super-homem" de Nietzsche. A raça era uma obsessão para os nazistas, que queriam manter o povo idêntico a si mesmo. ${ }^{83} \mathrm{O}$ Führer tinha repulsa ao ideário igualitário universal comunista, que contradiz o núcleo ideológico nazista, segundo o qual a "raça ariana" seria inerentemente superior, tendo, portanto, direito de dominar as demais, como acontece na natureza com alguns animais. Para ele, a História era guerra de raças, não de classes, como pensava Marx.

Por causa deste determinismo, a desigualdade era estabelecida pela natureza ou por designo divino, sendo absurda a teoria de filósofos modernos (liberais ou republicanos) ${ }^{84}$ que defendiam a existência de um estado natural de igualdade, a ser depois transferido para a sociedade, em grau variado. Para os nazistas, a comunidade era um produto orgânico da natureza, que reuniu pessoas do mesmo sangue e lhe deu uma tradição única. Ela foi destruída pelos filósofos modernos, que para justificar o

\footnotetext{
${ }^{80} \mathrm{Na}$ interpretação distorcida da teoria de Darwin, a vida social é uma luta pela sobrevivência que valoriza e premia os mais adaptados e esforçados. Para o precursor Herbert Spencer, o Estado não deve ajudar os desfavorecidos e os necessitados, porque estaria indo contra a natureza, retirando-lhe a "luta pela vida", a motivação para viver. Este pensamento foi depois radicalizado pelos nazistas: os "perdedores" dessa luta podem até ser eliminados.

81 A partir de características físicas da cabeça, a frenologia (criada pelo austríaco F. J. Gall em 1798) pretende prever a capacidade mental e o comportamento humano, sobretudo o criminoso. Foi utilizada por médicos alemães em experimentos com prisioneiros dos campos de concentração.

${ }^{82} \mathrm{O}$ termo foi criado por Francis Galton, significando "bem nascido". No livro Inquiries into buman faculty and its development, de 1883, Galton definiu eugenia como "o estudo dos agentes sob o controle social que podem melhorar ou empobrecer as qualidades raciais das futuras gerações, seja física ou mentalmente". Estava convencido de que era a natureza, não o ambiente e nem a sociedade, quem determinava as habilidades humanas. O racismo eugenista se espalhou nos EUA no início do século $\mathrm{XX}$, sob liderança de Charles Davenport, não contra os negros, mas contra os imigrantes, para construir sua imagem como pessoas doentes e depravadas. Ele estabelece padrões de comportamentos para definir categoria de indesejáveis (que não seguem aquelas normas) e fracassados. As qualidades são hereditárias e (para que as negativas não sejam passadas para os filhos), propõe esterilização, proibição de casamento, internação ou até extermínio (caso do nazismo).

83 Os judeus eram considerados pertencer a uma raça inferior. Essa ideia de "pureza da raça" surgiu na Espanha no século XVI, para proibir os casamentos mistos de judeus com católicos, mesmo que fossem conversos. A Igreja católica não aceitou tal argumento: os judeus deveriam ser descriminados e perseguidos pelos erros doutrinários e não por ser uma raça diferente. Apesar dessa oposição, a ideia acabou largamente aceita. Para os nazistas, os eslavos eram "animais", destinados a trabalho escravo. Mesmo as raças de origem germânica, como os ingleses, eram depreciadas porque "decadentes" (por ter desenvolvido a democracia e a tolerância, a partir do pensamento de Locke).

${ }^{84}$ Locke, Rousseau e outros. Também Hobbes, defensor do absolutismo, partilhava dessa concepção.
} 
desejo de mudanças da ordem existente, eliminaram a comunidade e inventaram que a sociedade seria um produto exclusivamente do homem, que por meio de um contrato social ou pela força juntou indivíduos isolados, sem uma tradição anterior em comum, sem laços comunitários. Essa seria a herança nefasta do Iluminismo, objetivada na Revolução Francesa. A igualdade política seria um pretexto das minorias ou dos grupos inferiores para diminuir o poder e o status da "verdadeira nação". O igualitarismo humanista não era considerado uma invenção das esquerdas, mas do Liberalismo, ou até do Cristianismo (melhor dizer: do judaico-cristianismo, uma religião "estrangeira"), fato que para os mais fanáticos justificava o desejo de cultivar um neopaganismo místico e buscar o retorno a uma "origem mais originária", a nórdica. EUA e URSS, Liberalismo e Bolchevismo, ambos igualitários, eram os dois braços do "alicate materialista" (metáfora heideggeriana) que estava destruindo a vida "espiritual" alemã.

Praticando uma intolerância extrema, os nazistas atacaram a democracia liberal de Weimar como degenerada e antinatural, e depois providenciaram a retirada de direitos de grupos considerados inferiores, porque esta igualdade era uma discriminação "ao contrário" e criava uma opressão exercida pelas minorias. ${ }^{85}$ Eles negavam a existência de direitos humanos, ${ }^{86}$ cuja defesa se baseia em crenças julgadas absurdas: a unidade do gênero humano e o seu significado moral; a existência de uma "pessoa humana" que não depende da característica concreta de cada indivíduo; uma natureza humana que justifica um direito natural; a primazia do indivíduo sobre as comunidades orgânicas e históricas, como as culturas, os povos e as nações.

A esquerda nunca utilizou o tema da raça, e sempre defendeu (pelo menos no papel) os direitos humanos. Na linha de Rousseau, deu mais ênfase à igualdade em geral, considerada um bem mais importante que a liberdade. ${ }^{87}$ Também os marxistas criticavam a democracia liberal, não por ser antinatural, mas porque era só formal, isto é, impedia aos desfavorecidos e explorados o exercício real de direitos e liberdades, previstos em lei. Afirmavam que o comportamento humano não depende da natureza, mas da sociedade e das relações de produção. Porém, desconheciam ou subestimaram o fato de que existem inclinações, mesmo não sendo hereditárias, e outros elementos psicológicos e irracionais, dos quais os demagogos nazistas de aproveitariam facilmente.

Portanto, o nazismo não surgiu da loucura de um líder ou do delírio de um povo anestesiado. Ele tentou pôr em execução uma série de pensamentos filosóficos pré-existentes: o ideário comunitário medieval, com a sua rígida e eterna divisão em estratos; o romantismo com o culto ao passado; várias ideias espiritualistas, nacionalistas e racistas do século XIX, que eram uma reação às ideias materialistas, universalistas e igualitárias do Iluminismo. Se concordamos que estas últimas ideias entraram a fazer

\footnotetext{
${ }^{85}$ Por exemplo, na Áustria e Alemanha, os judeus talvez eram 1-2\% da população, mas chegavam em até 10-15\% das atividades mais bem remuneradas ou valorizadas (médicos, professores, cientistas, etc.), despertando inveja e ressentimento. Assim, eles eram vistos como uma elite intelectual exploradora do povo.

86 Pensamento também presente em algumas correntes filosóficas (utilitaristas, românticos, historicistas).

${ }^{87}$ Nisso, está a maior crítica que lhe é feita pelos liberais. Por exemplo, Tocqueville, em O Antigo Regime e a Revolução, defendeu que a priorização da igualdade prejudicaria a liberdade individual, como aconteceu no período do "Terror". Antes, Montesquieu, em $O$ Espirito das leis, alertou contra o igualitarismo extremo.
} 
parte da ideologia esquerdista, que partiu do Liberalismo político e depois tentou superá-lo com o Marxismo, quando entrou na discussão o aspecto econômico, devemos concluir que nada de esquerdista existiu (e existe) no nazismo.

A partir da desigualdade natural, os nazistas justificaram e praticaram o belicismo, o colonialismo e o pangermanismo extremo. ${ }^{88} \mathrm{~A}$ esquerda se posicionou contra as guerras entre nações (fracassando, porém, no caso da Primeira Guerra Mundial, por ter ingenuamente subestimado o nacionalismo dos povos, a partir da confiança no internacionalismo proletário) e contra as guerras coloniais, porque elas só faziam o interesse dos capitalistas. Pelo contrário, apoiou os movimentos de independência e libertação nacional na África e Ásia, ${ }^{89}$ após o término da Segunda Guerra Mundial. Ela era internacionalista, ${ }^{90}$ enquanto que os nazistas defendiam um nacionalismo agressivo de dominação, que levou à Segunda Guerra Mundial e a uma política de extermínio.

Finalmente, um sétimo argumento aponta que os nazistas foram hábeis populistas ${ }^{11}$ em explorar de forma demagógica certos sentimentos que atingiam pessoas comuns desinformadas ou que se sentiam amaçadas pelos novos tempos e pela igualdade de direitos. Em Como funciona o fascismo, Stanley destaca alguns daqueles sentimentos: medo de perder a identidade nacional e cultural; ansiedade pela crise econômica; ressentimento pelas expectativas não atendidas e pela perda de uma pretensa superioridade ou do status dominante; vitimização. Em particular, há a espera de um líder messiânico e carismático que sabe interpretar a vontade do "povo" e resolverá tudo graças a seu grande ativismo, mesmo que para isso tenha que violar direitos e combater as instituições que regulam as relações sociais e limitam o poder; ele agirá contra as elites que, ou porque são corruptas ou porque estão a serviço do inimigo, não querem resolver os problemas, para os quais os populistas oferecem uma solução simples e de fácil compreensão pelas pessoas. ${ }^{92}$

Em época de crise e de desigualdade acentuada (tal era a da Alemanha no pós-guerra), era mais fácil para os nazistas colocar as pessoas umas contra as outras, achar culpados, inimigos históricos e bodes expiatórios. Eles recorriam à teoria da conspiração de "grupos financeiros", "poderes ocultos" e minorias, que estariam dominando os governos democráticos, as universidades e a imprensa, para explorar o povo portador dos autênticos valores da nação. Assim, os nazistas puderam criar a divisão entre "nós" e "eles" e instalar um regime totalitário. Recusavam o debate racional para evitar que fosse

\footnotetext{
88 Pensamento que quer reunir em um único país todos os alemães étnicos distribuídos em outras nações (França, Tchecoslováquia, Polônia, Hungria, Romênia, etc.): não os atraindo para a Alemanha, mas anexando aqueles territórios!

${ }^{89} \mathrm{O}$ nacionalismo de libertação é diferente do nacionalismo de dominação (como o nazista), porque busca a igualdade e não a superioridade. Por isso, foi defendido pelos esquerdistas.

${ }^{90}$ Nessa tendência, os nazistas incluíam os liberais e os cristãos.

${ }^{91}$ Há uma discussão se existe também um populismo de esquerda (no qual seriam incluídos, por exemplo, Juan Perón, Getúlio Vargas, Hugo Chávez). Pelo nosso entendimento, o populismo é sempre de direita, por causa das suas características: demagogia, oportunismo, discurso anti-intelectual e anticientífico. Quando surge um movimento de protesto sem um claro objetivo, ele será sempre instrumentalizado pela direita.

${ }^{2}$ Se o problema é a imigração, é só construir um muro; se é o desemprego, é só proibir as importações; se é o terrorismo, é só expulsar os muçulmanos; etc.
} 
comprovada a falsidade da sua propaganda, e apostavam na imaginação das pessoas em ver inimigos internos e externos. ${ }^{93}$ Seguia-se a crítica à educação humanística e ao intelectualismo.

Ficou assim evidente que os nazistas não podem ser considerados de esquerda, por causa dos valores, princípios e objetivos defendidos. Eles devem ser incluídos numa nova direita, a extrema direita, também porque a direita tradicional (nas várias vertentes: liberal, conservadora, reacionária, monarquista, clerical) os levou ao poder. Para isso, deviam ter algo em comum! Esse algo em comum era basicamente o anticomunismo, mas não só. Resumindo, os nazistas levaram ao extremo:

[...] o fascismo, uma ideologia política cujo centro mítico, em suas várias permutações, é uma forma de populismo ultranacionalista palingenético. [...] $\mathrm{O}$ fascismo teve que responder aos problemas que acompanharam as revoluções e à modernização em geral: a urbanização acelerada, a entrada das massas na política, a mobilização social e política de inspiração marxista, a ameaça da revolução social. [...] $O$ fascismo preserva seu caráter revolucionário não para alcançar uma sociedade ideal futura através de sérias mudanças na estrutura política, social e cultural da sociedade que chega a controlar, mas pelo fato de que efetua mudanças numa contínua luta, ou guerra, que é a característica básica da sua análise histórica. [...] Uma das principais manifestações de intolerância reside na magnitude e qualidade da exclusão. Elites políticas e intelectuais inteiras são excluídas, não apenas da prática política e cultural, através da censura e da perseguição, mas também definidas como supérfluas. [...] Uma série de conceitos centrais ao Iluminismo, como universalismo, humanismo, racionalismo, são vistos como categorias negativas ou simplesmente inimigas (Sznajder, 2010, p. 25-29).94

Apesar de discordar, citaremos para uma reflexão a posição do respeitado historiador John Lukacs, autor de O Hitler da História. Ele não classifica o nazismo na direita (mas tampouco na esquerda!) porque entende que:

Hitler não era um reacionário no sentido de desejar a volta a um passado imaginário ou a conservação de uma ordem social ameaçada. Ele teria se aliado à direita tradicional e contrarrevolucionária no sentido de atingir o poder, mas seria, antes de tudo, um "revolucionário nacionalista populista", cujo cuidado e habilidade em inflamar as massas mostraria a sua filiação à era democrática moderna e a impossibilidade de classificá-lo ao lado de conservadores preocupados com a mobilização popular. Ainda nessa linha de raciocínio, Hitler e o nazismo teriam superado as classificações de "esquerda" e "direita", totalmente inadequada para compreendê-los (Bertonha, 2008, p. $351)$.

\section{O SEGUNDO MOTIVO}

Passamos agora ao segundo ponto. Aqui, podemos destacar uma certa superficialidade nos argumentos apresentados pelos ideólogos do atual governo, sobre o uso da violência. Certamente,

\footnotetext{
93 Todos esses elementos são bem visíveis nos atuais movimentos populistas e de extrema direita na Europa e Américas. As novas minorias que ameaçam o status, a identidade e as tradições são os imigrantes, os refugiados, os movimentos negros, as feministas, etc.: enfim, todos os "diferentes".

${ }^{94}$ A palingênese é uma espécie de "renascimento nacional", quando os valores tradicionais estão sendo questionados ou destruídos pela Modernidade. A organizadora do livro cita a definição de Roger Griffin, autor de The nature of Fascism.
}

Revista Lumen, v. 4, nº 7, Jan./Jun. - 2019 - ISSN: 2447-8717 
nazistas e comunistas, mantendo ou conquistando o poder pela força, fizeram largo uso dela contra os opositores (inclusive os dissidentes internos ao seu próprio partido) e anulando as regras da democracia liberal.

Historicamente, porém, tal comportamento não foi exclusivo deles, por ser talvez uma característica do ser humano, que não tem freio quando age em grupo e é movido por fortes sentimentos. No Principe, Maquiavel mostrou que um governante, para manter o poder, deve usar as leis ou a força conforme a situação (mas a segunda é justificada somente para defender o bem comum da república e não o bem particular!), e a força é o que foi realmente utilizada desde que iniciou a História da humanidade, sem nenhuma exceção, por parte dos governantes de qualquer tendência. Tentar negar isso é pura hipocrisia.

Assim, o clima de terror, os massacres e as discriminações foram usados pela Igreja (a instituição dominante na Idade Média e no início da Moderna) por meio das Cruzadas, da Inquisição, das guerras de Religião, da instituição dos guetos. E, nas Idades Moderna e Contemporânea, aqueles meios foram utilizados pelas potências coloniais, que destruíram povos e culturas na América, Ásia e África; e por golpistas que instalaram ditaduras militares. Eles também recorreram a campos de concentração, que são uma marca dos regimes totalitários. Estes fatos, por ter acontecidos em tempos mais remotos, são facilmente esquecidos.

\section{CONCLUSÃO}

Claramente, seria um disparate acusar o atual governo de ser nazista ou fascista, também porque esses termos muitas vezes são usados de forma imprópria, só para desqualificar ou insultar o adversário. ${ }^{95}$ A vontade de praticar uma política de domínio do mundo e de extermínio de grupos inteiros a partir de teorias nacionalistas e racistas, felizmente, está bem longe do programa de qualquer governo, apesar de que tudo o que já aconteceu uma vez, pode acontecer de novo, como observou o escritor italiano Primo Levi, sobrevivente de Auschwitz. Daí, a necessidade de uma contínua vigilância.

No máximo, podemos dizer que nos governos dos quais participa a extrema direita, ${ }^{96}$ existem alguns traços da propaganda fascista, como: um gosto pelo autoritarismo, um desprezo pelas minorias, um incentivo indireto à xenofobia, um cansaço com o "politicamente correto", um discurso demagógico contra os políticos e as elites corruptas, um populismo superficial pela exaltação do "povo" como portador de valores tradicionais "verdadeiros", uma exploração do ressentimento popular, uma saudade

\footnotetext{
95 Muitos historiadores entendem que houve só dois regimes autenticamente fascistas, os de Mussolini e de Hitler. Outros governos somente apresentaram alguns traços fascistas: Franco na Espanha e Salazar em Portugal; os colaboracionistas na Hungria, Croácia, Eslováquia, Romênia durante a Segunda Guerra Mundial; as ditaduras militares na América Latina, Grécia e Turquia; os governos teocráticos em alguns países muçulmanos, etc.

${ }^{96}$ Trata-se de uma participação no governo, por parte de movimentos de extrema direita, em coalizão com outros partidos, e não de um governo exclusivo deles. Assim, eles são obrigados a seguir as regras do jogo democrático. No momento, além do Brasil, isso acontece nos EUA e vários países da União Europeia.
} 
do passado, um catastrofismo pelo qual tudo está pior do que antes, uma crítica aos métodos democráticos que não resolvem os problemas, etc. Assim, a intervenção para classificar o nazismo como pertencente à esquerda, não deve ser interpretada como uma autodefesa, mas uma tentativa de desqualificar ainda mais a esquerda atual.

Em todo caso, trata-se de uma tentativa malsucedida. Concluímos que a comparação feita pelos ideólogos do governo Bolsonaro mostra um profundo vazio filosófico e intelectual, a superficialidade dos argumentos, a incapacidade de análise da linguagem, um grave desconhecimento de ideias e fatos históricos. A diferença de princípios, valores e objetivos (quando bem definidos) é bem mais importante

109 do que o uso de um nome ("socialismo") que pode ter qualquer significado. O objetivo deste artigo não é defender o ideário esquerdista, mas de argumentar contra a absurda afirmação do nazismo ser de esquerda.

\section{REFERÊNCIAS}

BERTONHA, João Fábio. Sobre a Direita. Maringá: UEM, 2008.

FARIAS, Victor. Heidegger e sua berança. São Paulo: É Realizações, 2017.

LUKACS, John. O Hitler da História. Rio de Janeiro: Zahar, 1998.

MANN, Michael. Fascistas. Rio de Janeiro: Record, 2008.

MOUNK, Yascha. O povo contra a democracia. São Paulo: Companhia das Letras, 2019.

STANLEY, Jason. Como funciona o fascismo. Porto Alegre: L\&PM, 2018.

SZNAJDER, Mário. "Fascismo e Intolerância". In: TUCCI CARNEIRO, Maria Luiza (org.). Tempos de Fascismos. São Paulo: Edusp, 2010. 